\title{
A Review of Science Standard History Culminating With Next Generation Science Standards
}

\author{
R. Tyler Ames (corresponding author) \\ Department of Applied Sciences, Technology \& Education, Utah State University \\ 6000 Old Main Hill, Logan, Utah, 84322, United States
}

Tel: 1-801-602-0828Ｅmail: R.Tyler.Ames@gmail.com

Received: January 4, 2014 Accepted: February 7, 2014 Published: March 16, 2014

doi:10.5296/jet.v1i2.5292 URL: http://dx.doi.org/10.5296/jet.v1i2.5292

\begin{abstract}
When the USSR launched the satellite Sputnik shockwaves went through the United States. Science education was reformed and gains were made. Two decades after Sputnik, science education in the U.S. had regressed and a report from the government claimed that if the current state of education were imposed by another country it would be perceived as an act of war. The nation again mobilized in an attempt to rectify the perceived shortcomings in American education. Science for All Americans and Benchmarks in Science Literacy were first and closely followed by National Science Education Standards. All of these publications had dramatic effects on science education and American science education again moved forward. Another decade brought the world into the new century and found United States science education staying no more than afloat when compared globally. The National Research Council set out to determine what changes standards should undergo in order to best propel the United States as far forward as possible. They published A Framework for $K-12$ Science Education which was very influential and was the basis for the publication of the Next Generation Science Standards (NGSS). Polls show that the American public is ready and wanting new internationally-benchmarked science standards such as the NGSS are. The NGSS are heavily based on the three dimensions recommended in the Framework: Practices, Cross-Cutting Concepts, Core Ideas.
\end{abstract}

Keywords: science standards, next generation science standards, education reform 


\section{Introduction}

Education reform is not new and will never be completed (American Association for the Advancement of Science, 1989, p. 5). With the U.S. educational system trying to move forward, many new standards are being produced in areas such as math, English, and science. However, in order to understand present and newly developed science standards it is important to understand the history and story behind science standards in science education in the United States.

\section{Literature Review}

In 1956 science education reform took a substantial step forward when Jerrold Zacharias began the Physical Science Study Committee. One year later, the USSR launched Sputnik and the science educational reform movement of the era would never look the same. The prevailing sentiment after World War II had been a need to go "back - back to fundamentals, back to basics, back to drill and memorization, and back to facts" (Bybee, 2013, p. 13). The direction of educational reform halted its rear-facing march and moved firmly forward in a permanent cadence forever after the launch of Sputnik. Linked directly to the fear that gripped the country with the Sputnik's launch, the United States felt a need to push itself into a more uniform and forward moving science education reform. This was spurred on by President John F. Kennedy's clear goal for the country to go to the moon. He summoned Congress for a joint session in 1961 and laid out a clear view of his goal to land a man on the moon before the decade was over (Kennedy, 1961). He understood that science needed to take several steps forward to make this possible, as evidenced by his speech at Rice University in 1962:

We choose to go to the moon. We choose to go to the moon in this decade and do the other things, not because they are easy, but because they are hard. . . The growth of our science and education will be enriched by new knowledge of our universe and environment, by new techniques of learning and mapping and observation, by new tools and computers for industry, medicine, the home as well as the school. . . We shall send to the moon, 240,000 miles away from the control station in Houston, a giant rocket more than 300 feet tall, the length of this football field, made of new metal alloys, some of which have not yet been invented, capable of standing heat and stresses several times more than have ever been experienced, fitted together with a precision better than the finest watch, carrying all the equipment needed for propulsion guidance, control communications, food and survival, on an untried mission, to an unknown celestial body, and then return it safely to earth, re-entering the atmosphere at speeds of over 25,000 miles per hour, causing heat about half that of the temperature of the sun. .. we must be bold.

The United States landed Neil Armstrong and Buzz Aldrin on the moon in 1969 with Armstrong declaring those famous words, "One small step for man, one giant leap for mankind." It is clear from the feat accomplished that science moved forward as a whole. But science education also moved forward with it. Students who engaged in the new science curricula that were introduced in that era "performed better than students in traditional 
courses in general achievement, analytic skills, process skills, and related skills (reading, mathematics, social studies and communication), as well as developing a more positive attitude toward science" (Shymansky, Kyle, \& Alport, 1983). Science education was moving forward and improving at that time.

But a little more than a decade after the moon goal was complete, a study conducted by the National Commission on Excellence in Education painted a far grimmer picture. The committee, comprised of distinguished veteran educators, was commissioned to study the quality of American education. And they found results that were much worse than anticipated (Bell, 1993, p. 593). The report, entitled A Nation at Risk, concluded (United States. National Commission on Excellence in Education, 1983, p. 9) that

If an unfriendly foreign power had attempted to impose on America the mediocre educational performance that exists today, we might well have viewed it as an act of war. ... We have even squandered the gains in student achievement made in the wake of the Sputnik challenge. Moreover, we have dismantled essential support systems which helped make those gains possible.

The national regression and loss of previous gains was reiterated and confirmed by another publication, released in 1989, Science for All Americans (SFAA). The report called attention to the most recent National Assessment of Education Progress report, published in 1986, and reported that "despite some small recent gains, the average performance of 17 -year-olds in 1986 remained substantially lower than it had been in 1969" (AAAS, 1989, p. 2).

SFAA emphasized the need for science "literacy." The reasons that the report gives for demanding science literacy range from national self-interest, to individual self-fulfillment, to global necessity in the face of problems like acid rain, a growing global population, and shrinking of tropic rain forests. The stumbling block to a solid national science education effort appeared to be crushing teaching loads, absence of a modern support system, and overstuffed and undernourished science curricula. In order to provide more focus and encourage efficiency the report gave several recommendations in the form of chapters. Each chapter presented a "major set of related topics" (p. 6) that teachers were encouraged to draw from. The publication was not intended to be used as a curriculum document or a textbook, but to inform teachers of appropriate learning goals.

Immediately after its release, the American Association for the Advancement of Science formed six teams each comprised of 25 teachers and administrators to study ways that science literacy goals could be attained. These teams worked for four summers and three academic years to produce a follow-up publication to SFAA that culminated in 1993: Benchmarks for Science Literacy. The purpose of Benchmarks was to be used alongside of $S F A A$ and to complement it. "SFAA presents a vision of science literacy goals for all students to reach by the time they finish the $12^{\text {th }}$ grade, and Benchmarks maps out the territory that students will have to traverse to get there" (AAAS, 1993, p.3). Benchmark does not try to be curriculum of any sort but seeks to be a tool for educators creating curriculum. It purposely sheds only partial light on how one might attain the different goals the publication expresses. And finally, Benchmarks built on a deep foundation of research - namely all "the relevant research 
literature in the English language (and some in other languages)" (AAAS, 1993, p.4).

Influenced heavily by both SFAA and Benchmarks, and at the request of the National Science Teachers Association (and with the encouragement of the U.S. secretary of education), the National Research Council a set of Science standards for the United States (National Research Council, 1996, p.14). Published in 1996 and entitled National Science Education Standards, teachers had access to content standards that detailed "what students should know, understand, and be able to do in the natural sciences over the course of K-12 education" (NRC, 1996, p.6). Together, the National Science Education Standards and Benchmarks for Science Literacy were used to inform and influence state science standards all around the country. (NGSS, 2013a).

A decade and a half passed and new research was published about education. Owing to the desire to improve education (NRC, 2012, p.1) the National Research Council again convened to discuss the national science standards. The first publication they produced came in 2011 and was entitled A Framework for K-12 Science Education: Practices, Crosscutting Concepts, and Core Ideas. The framework was produced upon "a rich and growing body of research on teaching and learning in science, as well as on nearly two decades of efforts to define foundational knowledge and skills for K-12 science and engineering" (NRC, 2012, p.2). The NRC asserts in the Framework that K-12 science education "is not organized systematically across multiple years of school, emphasizes discrete facts with a focus on breadth over depth, and does not provide students with engaging opportunities to experience how science is actually done" (p. 1). To overcome these challenges, the publication suggests focusing, as the title suggests, on three categories of science education: practices, crosscutting concepts, and a limited number of core ideas. It recommended that each standard be focused around those three things and that the focus be put upon quantifiable performance. Four disciplines for K-12 students to learn about were selected: Physical sciences; life Sciences; earth and space sciences; and engineering, technology, and applications of science. Each discipline would contain multiple standards and each standard would be broken up and presented in the three dimensions discussed above, with an overarching emphasis in performance.

The action that the Framework called for began; expert committees were formed, lead states were selected, and six different drafts were released to for feedback with edits made between every draft (NGSS, 2013b). With that, the new standards were born in April of 2013 and entitled The Next Generation Science Standards.

\section{Discussion}

The release of the NGSS coincides with a strong national belief that science education is vital to the United States' ability to compete with the rest of the world. A poll of the general U.S. public found that $97 \%$ of Americans - a virtual unanimity - believe that "improving the quality of science education is important to the United States' ability to compete globally" (Achieve, 2012, p. 1). Research agrees with public opinion in this case as "several reports have linked K-12 (Science, Technology, Engineering, and Mathematics) STEM education to continued scientific leadership and economic growth in the United States" (NRC, 2011, p.3; National Academy of Sciences, National Academy of Engineering, and Institute of Medicine, 
2007). Reflecting the national sentiment that we need to be current in Science, STEM education is receiving large support from all quarters of the country. A variety of STEM thinking models show that Science never takes second place when compared with any of the other three (Bybee, 2013, p. 74-79). Even large companies in the private sector are supporting STEM education by giving large sums of money in grants. Google supports the development of a national STEM teacher corps and gave \$40 million in STEM grants in 2011 (Koebler, 2011). The Toyota USA Foundation donated \$1.3 million in STEM grants (Toyota, 2012). President Barack Obama stated, "Leadership tomorrow depends on how we educate our students today_especially in science, technology, engineering and math" (Sabochik, 2010).

Tomorrow depends on our STEM education, yet United States test scores in science and math are merely average when compared with test scores of the rest of the developed world (see Table 1; Bybee, 2013). There are two globally recognized tests that are appropriate in this context: the Program for International Student Assessment (PISA) and Trends in International Mathematics and Science Study (TIMMS). The international tests used to test these areas have their critics and while it is not the intent of this paper to accredit or discredit the tests, the results appear to be fairly clear in one regard - the U.S. is not the global leader. A poll revealed that the general public appears to sense the country's mediocrity; a majority of Americans (67\%) give science education in the U.S. a grade of "C" or below (Achieve, 2012, p.1).

Table 1. Mean Scores on 2012 PISA for the Top Ten Performers Compared to the United States (Organisation for Economic Co-operation and Development, 2012)

\begin{tabular}{|l|l|l|l|l|l|}
\hline Rank & Country & $\begin{array}{l}\text { Math Score } \\
\text { (OECD } \\
\text { Average } \\
\text { Score: } 494)\end{array}$ & Rank & Country & $\begin{array}{l}\text { Science Score } \\
\text { OECD } \\
\text { Average } \\
\text { Score: 501) }\end{array}$ \\
\hline 1 & Shanghai & 613 & 1 & Shanghai & 580 \\
\hline 2 & Singapore & 573 & 2 & Hong Kong & 555 \\
\hline 3 & Hong Kong & 561 & 3 & Singapore & 551 \\
\hline 4 & Taipei & 560 & 4 & Japan & 547 \\
\hline 5 & Korea & 554 & 5 & Finland & 545 \\
\hline 6 & Macao & 538 & 6 & Estonia & 541 \\
\hline 7 & Japan & 536 & 7 & Korea & 538 \\
\hline 8 & Liechtenstein & 535 & 8 & Viet Nam & 528 \\
\hline 9 & Switzerland & 531 & 9 & Poland & 526 \\
\hline 10 & Netherlands & 523 & 10 & Canada & 525 \\
\hline 36 & United States & 481 & 28 & United States & 497 \\
\hline
\end{tabular}


The TIMMS report exposed a similar finding. The 2011 results revealed U.S. mathematics as being among the top 24 education systems in mathematics, and U.S. science among the top 23 education systems for science. And what is more, improvement for the nation has actually stalled-the TIMMS test in 2007 revealed no measureable improvement for either mathematics or science in the United States (Provasnik et al., 2012).

Underscoring the urgency for improvement in the country's science education are the results from the National Center for Education Statistics. The 2011 results reveal that more than a third of American $8^{\text {th }}$ grade students scored below basic achievement levels in science. $87 \%$ of Americans support the development of new science standards that are internationally-benchmarked and more challenging (Achieve, 2012, p. 1). Such a description is exactly what the NGSS aims to be. Near the end of the NGSS development process the National Research Council selected individuals who were experts with the Framework to study the NGSS and invited a critique to find areas where the NGSS might not be consistent with the Framework. The resulting critique was encouraging: "The review process determined that the NGSS, released to the public in April of 2013 and published in this volume, are consistent with the content and structure of the Framework" (NRC, 2013).

The Next Generation Science Standards will take a little bit of time to implement. In order to fully implement them, a state must first adopt them. To date, only seven states have formally adopted the NGSS: California, Delaware, Kansas, Kentucky, Maryland, Rhode Island, and Vermont. The second step is to phase in the new standards. Of the states that have adopted the NGSS, none are implementing them immediately. The earliest that any state will officially implement the standards is the 2014-2015 academic year, several will use a four-year path toward implementation, while others will wait longer; in some cases they will wait until 2017-2018 to implement the NGSS (NGSS, 2013c). And these are only the plans for the states who have already taken the first step of formal adoption. Rodger Bybee supports the gradual change, citing the enormous demands that reform places on teachers. He suggests an evolutionary approach to change instead of revolutionary (2013, p.27). It takes years to effect large reform like the NGSS are (Bybee, 2013, p. 9). The phase-in is exactly what is necessary for the NGSS to succeed.

\section{Dimensions}

In order for anyone to fully understand what will be implemented, and what the NGSS are, it is first imperative to understand the three dimensions that each standard is divided into as recommended by the Framework (Pratt, 2013, p. 7). As noted previously, the three dimensions are: core ideas, crosscutting concepts, and practices.

\subsection{Core Ideas.}

The core ideas identified by NGSS research teams for use in the NGSS were identified and evaluated through a study of relevant research and multiple key documents including both the National Science Education Standards and the Benchmarks for Science Literacy. In order for a concept to be included in the NGSS as a core idea it had to meet two of the following four criteria (NGSS, 2013a): 
1. Have broad importance across multiple sciences or engineering disciplines or be a key organizing principle of a single discipline.

2. Provide a key tool for understanding or investigating more complex ideas and solving problems.

3. Relate to the interests and life experiences of students or be connected to societal or personal concerns that require scientific or technical knowledge.

4. Be teachable and learnable over multiple grades at increasing levels of depth and sophistication.

Using this process, core concepts were identified for all four of the major discipline categories as specified by the Framework: physical sciences, life sciences, earth and space sciences, and engineering, technology, and applications of science.

\subsection{Crosscutting Concepts.}

Crosscutting concepts are the skeleton on which all other scientific learning is placed. In order for students to effectively process and build a correct and functional mental understanding of science, they must first have a foundation or framework to begin making correct sense of the ideas that they learn. "Some important themes pervade science, mathematics, and technology and appear over and over again" (AAAS, 1989). Applicable crosscutting concepts are listed under each standard and teachers are encouraged to directly teach and highlight them (NRC, 2012, p. 83). The NGSS standards and topics are interwoven with the following seven crosscutting concepts: Patterns; Cause and Effect; Scale, Proportion, and Quantity; Systems and System Models; Energy and Matter; Structure and Function; and Stability and Change (NGSS, 2013a). Each time one of these concepts is recommended for inclusion in the teaching of any standard an explanation of its importance is explained in context of the specific standard.

\subsection{Practices.}

There has long been tension in the educational world surrounding the balance between teaching students how to engage mentally as a scientist and how to engage practically as a scientist. The former, the knowledge base, must be built and is indispensable but neglect of practice leaves students with "naïve" beliefs about "the nature of scientific inquiry" and gives "the impression that science is simply a body of isolated facts" (NRC, 2012, p. 41). The Framework stressed the constant connection that should be attempted between the knowledge they gather and related practice (2012, p. 41). The word "practice" was deliberately chosen over the word "skill" in order to "emphasize that engaging in scientific inquiry requires coordination of both knowledge and skills simultaneously. Use of the term practices helps avoid the interpretation of skill as rote mastery of an activity or procedure" (NGSS, 2013a).

But the NGSS not only includes scientific practices, it also includes engineering practices. Inclusion of engineering practices not only provides additional real world connections, it also helps strengthen overall STEM education (NGSS, 2013a). 


\section{Conclusion}

The NGSS is not curriculum (Pratt, 2013, p. 15) but it will have a significant impact on science education moving forward. A recent poll of the National Science Teacher Association's 55,000 members revealed that about 80 percent agreed that the NGSS "would have a huge impact on the way they teach" (Schachter, 2013). The change will be gradual and some states may not even fully adopt the NGSS. But science educators around the country are taking note of the release of the new standards, regardless of their state's official position, and that will have a cumulative effect everywhere.

Obstacles will undoubtedly arise. Not all teachers feel comfortable adapting, or even want to adapt their lesson plans and teaching styles to accommodate new standards. For administrators, challenges will come as funding will need to be secured to support training. And quite simply, changing a national landscape cannot happen overnight. But an improvement will not happen if nothing is attempted. Here is the United States' attempt to improve, and it is a good one.

These standards will help move science education forward in the United States. They are simple, unencumbered, researched, and they will benefit students all around the country. It is true that educational reform is not new, and it will never be finished, but the current step aimed at benefiting the next generation is exciting and appears to be a step forward.

\section{References}

Achieve. (2012). Attitudes toward science education: Key findings from a national survey. Retrieved from http://www.nextgenscience.org/sites/ngss/files/AttitudesTowardScienceEducation1 pagerv6.p df

American Association for the Advancement of Science. (1989). Science for all Americans. Project 2061. Oxford University Press. Retrieved from http://www.project2061.org/publications/sfaa/online/sfaatoc.htm

American Association for the Advancement of Science. (1993). Benchmarks for science literacy. Project 2061. Oxford University Press. Retrieved from http://www.project2061.org/publications/bsl/online/index.php

Bell, T. H. (1993). Reflections one decade after “A Nation at Risk.” Phi Delta Kappan. 74(8), 592-597.

Retrieved

from

http://connection.ebscohost.com/c/articles/9305140276/reflections-one-decade-after-nation-ri sk

Bybee, R. W. (2013). The case for STEM education: Challenges and opportunities. National Science Teachers Association Press. Arlington, Virginia.

Kennedy, J. F. (1961). Special message by the president on urgent national needs before a joint session of Congress. May 25.

Kennedy, J. F. (1962). John F. Kennedy Moon Speech - Rice Stadium. Nasa.gov. Retrieved 
from http://er.jsc.nasa.gov/seh/ricetalk.htm

Koebler, J. (2011). Google awards grants to 16 STEM organizations. Retrieved from http://www.usnews.com/news/blogs/stem-education/2011/12/14/google-awards-grants-to-16stem-organizations

National Academy of Sciences, National Academy of Engineering, and Institute of Medicine. (2007). Rising above the gathering storm: Energizing and employing America for a brighter economic future. Washington, DC: The National Academies Press.

National Research Council. (1996). National science education standards. National Academy of Science. Washington, DC: The National Academies Press

National Research Council. (2011) Successful K-12 STEM education: Identifying effective approaches in science, technology, engineering, and mathematics. Committee on Highly Successful Science Programs for K-12 Science Education. Board on Science Education and Board on Testing and Assessment, Division of Behavioral and Social Sciences and Education. Washington, DC: The National Academies Press.

National Research Council. (2012). A Framework for K-12 Science Education: Practices, Crosscutting Concepts, and Core Ideas. Committee on a Conceptual Framework for New K-12 Science Education Standards. Board on Science Education, Division of Behavioral and Social Sciences and Education. Washington, DC: The National Academies Press.

National Research Council. (2013). National Research Council Review of the Next Generation Science Standards. Retrieved from http://www.nap.edu/NGSS/Memo-on-NRC-review-of-NGSS.pdf

Next Generation Science Standards Lead States. (2013a). Next Generation Science Standards: For States, By States (Frequently asked questions). Achieve, Inc. on behalf of the twenty-six states and partners that collaborated on the NGSS. Retrieved from http://www.nextgenscience.org/frequently-asked-questions

Next Generation Science Standards Lead States. (2013b). Next Generation Science Standards: For States, By States (Development Process). Achieve, Inc. on behalf of the twenty-six states and partners that collaborated on the NGSS. Retrieved from http://www.nextgenscience.org/development-process

Next Generation Science Standards Lead States. (2013c). Next Generation Science Standards: For States, By States (Delaware $7^{\text {th }}$ State to Adopt NGSS). Achieve, Inc. on behalf of the twenty-six states and partners that collaborated on the NGSS. Retrieved from http://www.nextgenscience.org/delaware-7th-state-adopt-ngss

Organisation for Economic Co-operation and Development. (2012). PISA 2012 rankings. Retrieved from http://www.oecd.org/pisa/keyfindings/pisa-2012-results-volume-i.htm

Pratt, H. (2013). The NSTA reader's guide to the Next Generation Science Standards. Arlington, VA: NSTA Press. 


\section{Macrothink}

Provasnik, S., Kastberg, D., Ferraro, D., Lemanski, N., Roey, S., \& Jenkins, F. (2012). Highlights from TIMSS 2011: Mathematics and science achievement of U.S. fourth-and eighth-grade students in an international context (NCES 2013-009). National Center for Education Statistics, Institute of Education Sciences, U.S. Department of Education. Washington, DC.

Sabochik, K. (2010). Changing the equation in STEM education. Retrieved from http://www.whitehouse.gov/blog/2010/09/16/changing-equation-stem-education

Schachter, R. (2013). Get ready for nextgen science. Retrieved from http://www.districtadministration.com/article/get-ready-nextgen-science

Shymansky, J. A., Kyle, W. C., \& Alport, J. M. (1983). The effects of new science curricula on student performance. Journal of Research in Science Teaching, 20(5), 387-404. http://dx.doi.org/10.1002/tea.3660200504

Toyota. (2012). Toyota USA Foundation announces $\$ 1.3$ million in new grants. Retrieved from

http://pressroom.toyota.com/releases/toyota+usa+foundation+announces + millions + new + gran ts.htm

United States National Commission on Excellence in Education. (1983). A Nation at Risk: The Imperative for Educational Reform. Retrieved from http://datacenter.spps.org/uploads/sotw_a_nation_at_risk_1983.pdf

\section{Copyright Disclaimer}

Copyright reserved by the author(s).

This article is an open-access article distributed under the terms and conditions of the Creative Commons Attribution license (http://creativecommons.org/licenses/by/3.0/). 